\title{
AN EPISODE OF LATE BLIZZARD, 25-26 MARCH 2013
}

\section{Danciu-Ciurlãu Doruța ${ }^{1}$,}

Key words: blizzard, climatic risk, North Atlantic Oscillation climatological and synoptic analyses, socio-economical impacts

\begin{abstract}
Climatologically speaking, March is a month of transition, from the cold season to a less cold season, and, therefore, weather phenomena occur in a different way from how they usually do during the cold season. The transition between seasons or a late winter can sometimes cause phenomena that usually happened in January or February, at the end of March. Such a case was the snowstorm occurred in two episodes $\left(22^{\text {nd }}-24^{\text {th }}\right.$ and $25^{\text {th }}-27^{\text {th }}$ of March 2013) in Romania in March 2013. In this paper is analyzed the first episode which affected southeastern Romania from different points of view: climatologically, synoptically, economically and social. It was used climatologically data over a period of 112 years, as well as a data for the first 3 month of 2013 which were provided by the National Meteorological Administration (NMA). It has been used synoptic maps, different pressure levels maps, and satellite data, radar data, soundings, all provided by the National Center of Weather Forecast of the NMA. Other type of information from the General Inspectorate for Emergency Situation (IGSU) or other ministries and media were also taken into consideration.
\end{abstract}

\section{Introduction}

In mid latitude, adverse weather can sometimes be very severe, being classified by some authors as "extreme weather events" (Moldovan, 2003) or as "climate risk phenomena" (Ciulache and Ionac, 1995). Blizzard is classified as a weather risk phenomenon typical for the cold season, but sometimes it may also occur in the transition seasons, in late fall or early spring in the third decade of March (e.g. the blizzards in two episodes: 22 -24 and 25-27 March 2013).

The climate of the south-east Europe region exhibits a marked variability, which has an enormous impact on people and their life.

1 Ph.D. Student, University of Bucharest; Meteorologist, National Meteorological Administration, dora.ciurlau@gmail.com 
Due to intensity and associated phenomena (high wind velocity, significant snow falls, reduced horizontal and vertical visibility, large air temperature), such snowstorms can be very dangerous to the human society activities, often putting human lives in danger. Transports, agriculture and energetic industry are most frequently and severely affected.

In winter of the 2012-2013, a severe snowstorm occurred in December 2012 in a few episodes (6-10, 12-15 and 18-22). January and February 2013 are characterized as "mild" mounts. Therefore, the blizzards in the third decade of March are astonishment in the weather forecast.

The purpose of this paper is to describe a detailed observational weather risk phenomenon as blizzard using the architecture of weather data.

\section{Data and methods}

The weather data used in this paper were provided by the NMA, the main source of data. In order to analyze the occurrence of the phenomenon were used data from a period of 113 years (1900-2013), for the months March and April. The analysis of the snowstorm episode from $25^{\text {th }}-27^{\text {th }}$ of March 2013 is based on hourly sea level pressure maps, weather reports and warnings issued by the NMA in the period of reference. Were also used some observational data as air temperature, pressure, rainfall, wind, other associated weather phenomena, etc. The synoptic analysis was based on the topography of sea level pressure and altitude maps, radar and satellite imageries provided by some open-access specialized sites such as: www.wetter3.de; http://weather.uwyo.edu/; www.nooa.gov, as well as soundings provided by the NMA. To roughly asses the damages we used releases from various ministries, the IGSU and information media.

\section{Climatological state}

Using the climatologically aspects were detected 42 episodes of blizzard, summing 104 days with blizzard. 1958 was the year when the biggest number days with blizzard were recorded in March (12). The latest date of when blizzard happened in a less cold season was $8^{\text {th }}-9^{\text {th }}$ of April 1911, besides that, in April only two episodes of blizzard were registered during all the 113 years analyzed.

A climatological research over the entire analyzed period of 113 years reveals that 40 cases of blizzard happened during the March, the latest of them on the $27^{\text {th }}$ $-31^{\text {st }}$ of March 1907

In general blizzard occurred in Romania in a specific cut-off configuration due to the North Atlantic Oscillation (NAO) negative phase, and for this reason an analysis of the NAO Index was also used. 
Using the NCEP/NCAR data was plotted the NAO index for the period between 1950 and 2013 (Fig.1). Therefore, 6 cases of March blizzards were happened when NAO was on the positive phase and 16 cases of March blizzards were on the NAO negative phase, with a lowest value in 17-18 March $1962(-2.99)$

Table 1.1 Number of cases with blizzard for March and April 1900-2013

\begin{tabular}{|c|c|c|c|c|c|c|c|c|c|c|}
\hline Year & March & April & Year & March & April & Year & March & April & Year & March \\
\hline 1900 & 1 & & 1940 & 2 & & 1968 & 2 & & 1987 & 1 \\
\hline 1904 & & 1 & 1949 & 1 & & 1969 & 2 & & 1988 & 1 \\
\hline 1907 & 3 & & 1952 & 1 & & 1971 & 1 & & 1992 & 1 \\
\hline 1911 & 1 & 1 & 1955 & 4 & & 1972 & 1 & & 1993 & 2 \\
\hline 1915 & 1 & & 1958 & 1 & & 1973 & 1 & & 1995 & 1 \\
\hline 1917 & 1 & & 1962 & 1 & & 1974 & 1 & & 2006 & 1 \\
\hline 1928 & 2 & & 1963 & 1 & & 1981 & 1 & & 2010 & 1 \\
\hline 1931 & 1 & & 1964 & 1 & & 1983 & 1 & & 2013 & 2 \\
\hline
\end{tabular}

(Source: NMA, 2013)

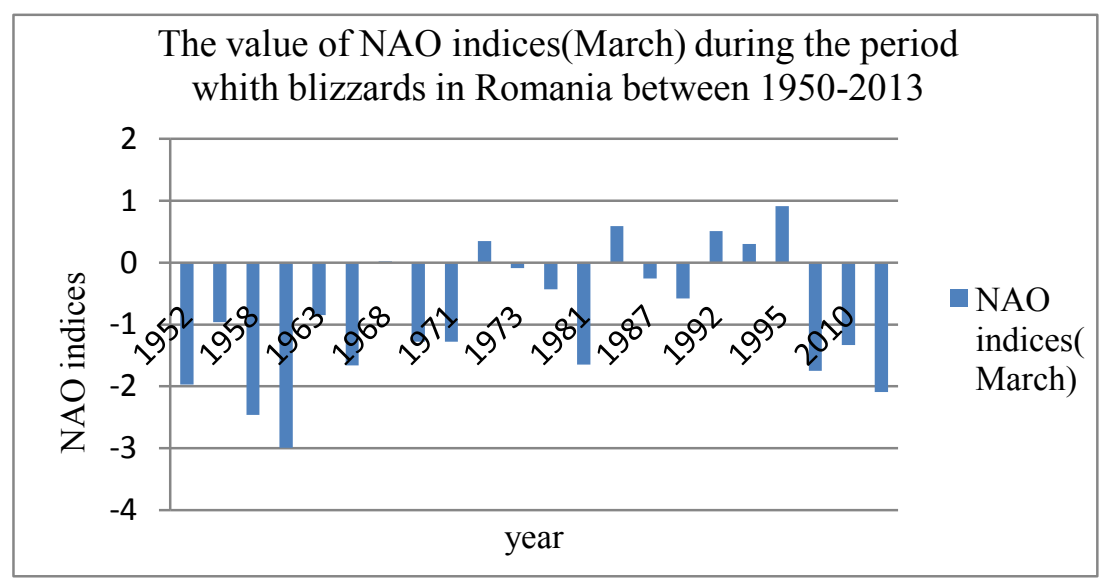

Fig. 1 NAO index value for March in Romania, (Source: http://www.cpc.ncep.noaa.gov)

\section{Case study: 25-26 March 2013}

As an example, it is taken into consideration the event occurred from the $25^{\text {th }}$ until the $26^{\text {th }}$ of March. The synoptic overview of the blizzard episode is characterized by the analysis of the sea level pressure and altitude maps during the period between $24^{\text {th }}$ to the $27^{\text {th }}$ March that can be seen in the next charts. 
The GFS model $500 \mathrm{hPa}$ level map (Fig.2) describes the outbreak of the phenomenon in our country, in Europe, the synoptic configuration was the following: on the $24^{\text {th }}$ of March 2013, the northern half of the continent was under the influence of the northern European anticyclone joining with the Scandinavian one, on the back of which the Icelandic cyclone was positioned, with $\mathrm{N} \rightarrow \mathrm{S}$ orientation, extending to the Mediterranean Sea basin, with a well-defined nucleus in the western British Isles, but advancing rapidly towards the Mediterranean basin, where we find it on $25^{\text {th }}$ of March with a well developed nucleus in the Gulf of Genoa, displaying a $\mathrm{S} \rightarrow \mathrm{E}$ trajectory and, reaching on $26^{\text {th }}$ of March over the Balkans and the southern part of our country.

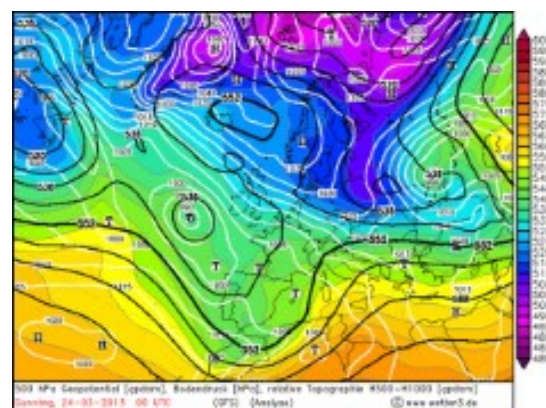

a.

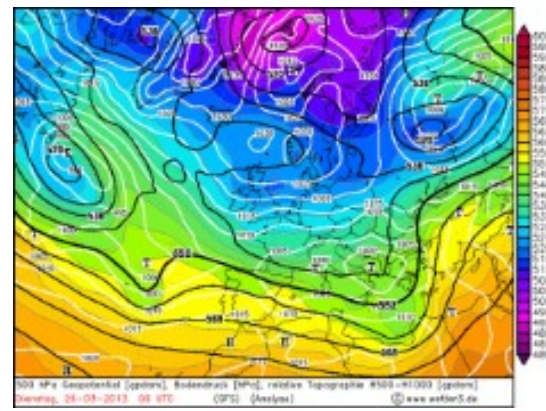

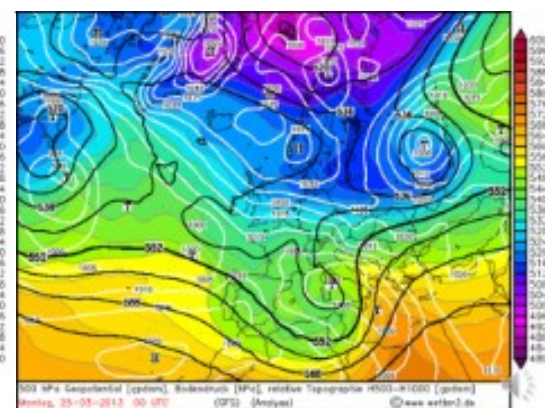

b.

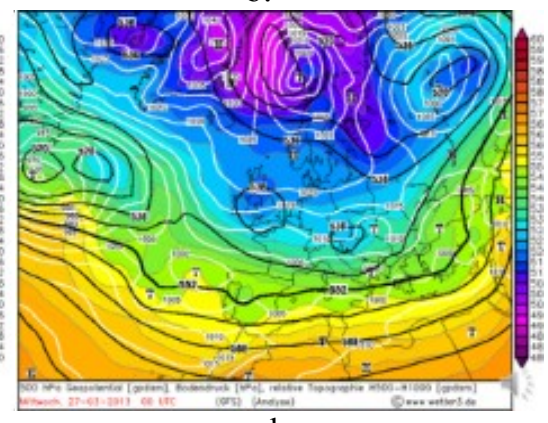

d.

Figure 2. GFS numerical model analysis - synoptic maps $500 \mathrm{hPa}$ at 00:00 UTC for March $24^{\text {th }}(\mathrm{a}), 25^{\text {th }}(\mathrm{b}), 26^{\text {th }}$ (c) and $27^{\text {th }}(\mathrm{d})$, (Source:www.wetter3.de)

The GFS model sea level pressure map (Fig.3) describes that on March the $24^{\text {th }}$, Europe was dominated by an anticyclone belt positioned in northern Greenland, and extending over the British Islands up to Central Europe, along $\mathrm{NV} \rightarrow \mathrm{SE}$ direction; behind it lying a low pressure field which originated in Iceland and extended from the eastern part of the Atlantic basin, up to the Mediterranean basin. The front line was stretching from the south of the British Islands to Western 
Europe. On the $25^{\text {th }}$ of March, the anticyclone belt changed its direction, placing itself over the continent, on a $\mathrm{V} \rightarrow \mathrm{E}$ direction, and reaching up to south-eastern Europe, where lies until the next day. The cyclonic field, at its back, develops over the Gulf of Genoa, and from there, it advances on $\mathrm{V} \rightarrow \mathrm{E}$ direction, over the Balkan Peninsula, where it reaches the southern part our country on the $26^{\text {th }}$ of March.

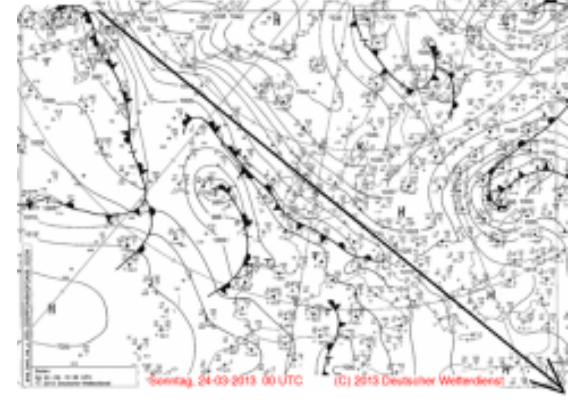

a.

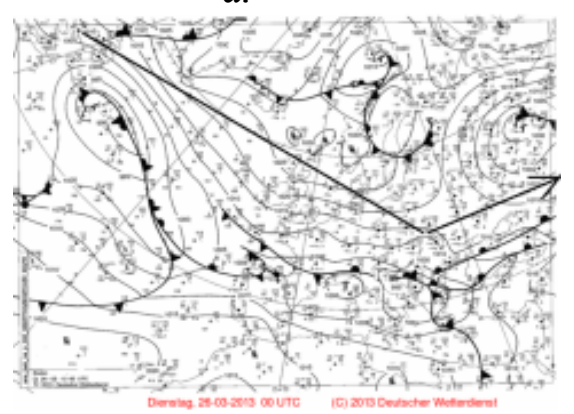

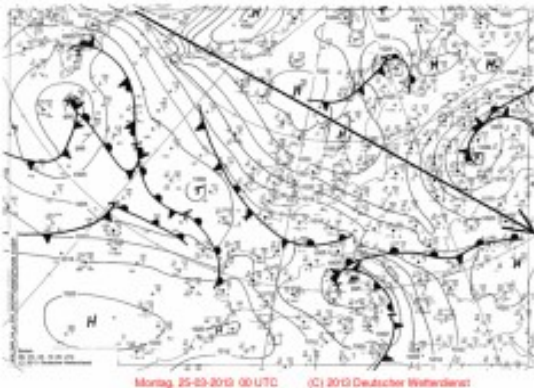

b.

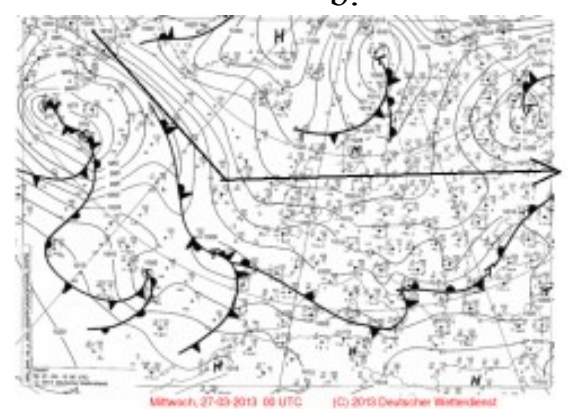

Figure 3. GFS numerical model analysis - sea level pressure at 00:00 UTC for March $24^{\text {th }}(\mathrm{a}), 25^{\text {th }}$ (b), $26^{\text {th }}$ (c) and $27^{\text {th }}(\mathrm{d})$, (Source: www.wetter3.de)

The thermally according to the $850 \mathrm{hPa}$ synoptic maps (Fig.4), GFS analysis model, on the $24^{\text {th }}$ of March at 00 TMG, the northern part of the continent was under the influence of cold air masses of Arctic origins, $0^{\circ} \mathrm{C}$ isotherm crossing the continent on a NW $\rightarrow$ SE direction, and orienting to, the southern parts of the country, along the Southern Subcarpathian Hills while to the south a mass of Mediterranean warm and humid air mass was pretty active. On the $25^{\text {th of }}$ March, the $0^{\circ} \mathrm{C}$ isotherm is shifts to the south, following the Danube basin, this situation remaining also unchanged on March the $26^{\text {th }}$. Due to the violent interaction between the two air masses on the $26^{\text {th }}$ of March a snowstorm phenomenon therefore developed affecting Romania's SE regions for about 11 hours. 
A "cross section" of temperature in the March $26^{\text {th }}$ shows that in Sibiu (central part of Romania) was measured the highest value and one day before, same location had the lowest temperature value. One day later, the temperatures values suffered a slight drop, especially at Sighetu Marmaţiei and Bistriţa (7 degree Celsius), lowest absolute temperature being recorded at Miercurea Ciuc(-11 degree Celsius).

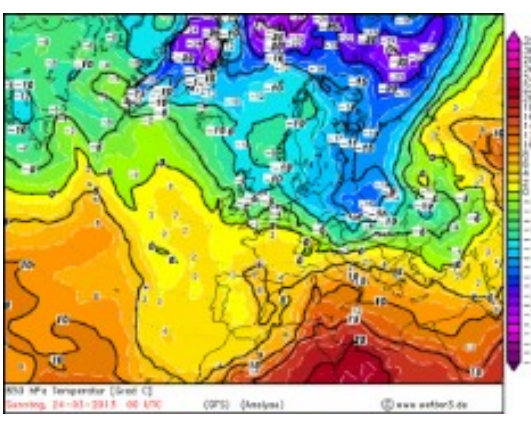

a.

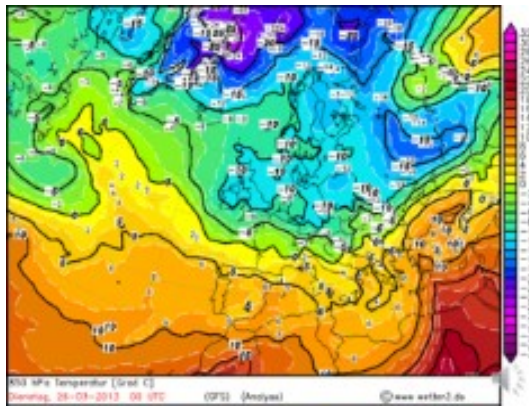

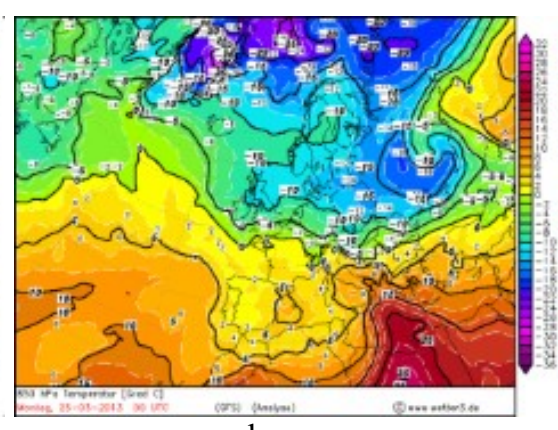

b.

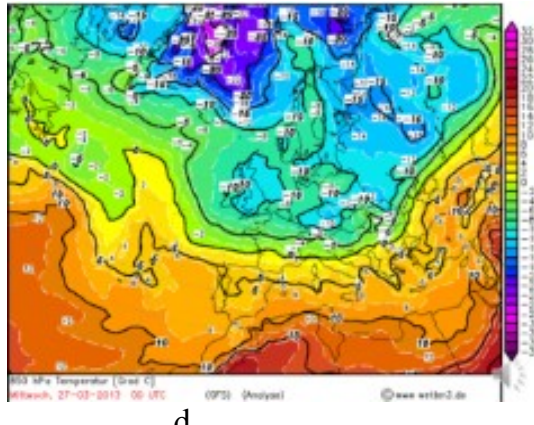

Fig. 4 Temperature maps at $850 \mathrm{hPa}, 00: 00 \mathrm{UTC}$, GFS analysis modelMarch $24^{\text {th }}(\mathrm{a}), 25^{\text {th }}(\mathrm{b}), 26^{\text {th }}$ (c) and $27^{\text {th }}(\mathrm{d})$, (Source:www.wetter3.de, 2013)

Synoptically overview of the meteorological phenomena from $24^{\text {th }}-27^{\text {th }}$ of March showed negative trend in their succession from rainfall at the start of the period, to snowfall and blizzard on the $25^{\text {th }}$ and $26^{\text {th }}$ of March especially in Southern and South-Eastern areas, highest blizzard intensity being situated in Bãrãgan (Fig.5), in the same areas atmospheric precipitation also being recorded was of $17.61 / \mathrm{m}^{3}$ at Galaţi on the $26^{\text {th }}$ of March.

On the $25^{\text {th }}$ of March there was snow in Crișana, Transylvania and Moldova, on the $26^{\text {th }}$ of March, the snow covered most of the country, except Dobrogea, 
where snow was recorded only on the $27^{\text {th }}$ of March as the rest of the country was already covered by it (Fig. 6).

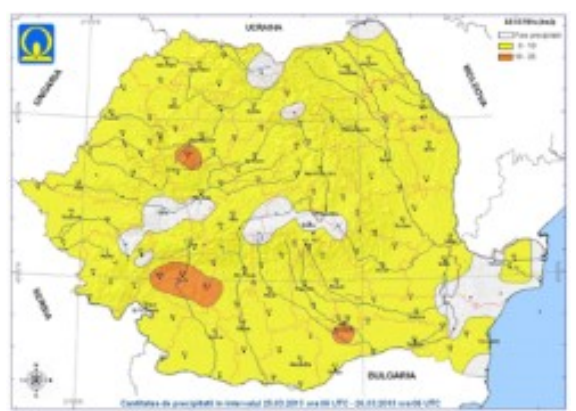

a.

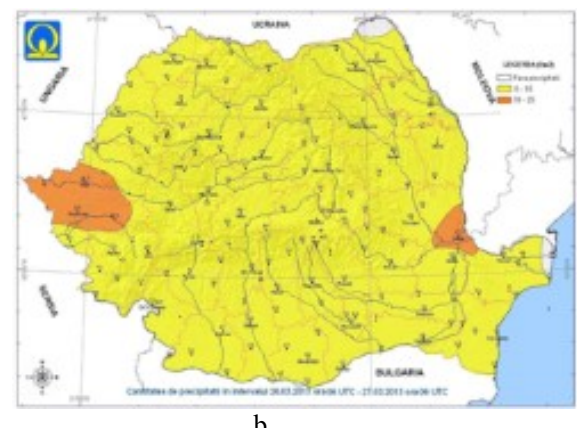

Fig.5 Rainfall amounts recorded in 24 hours: March, $25^{\text {th }}$ (a), $26^{\text {th }}$ (b), (Source: NMA, 2013 )
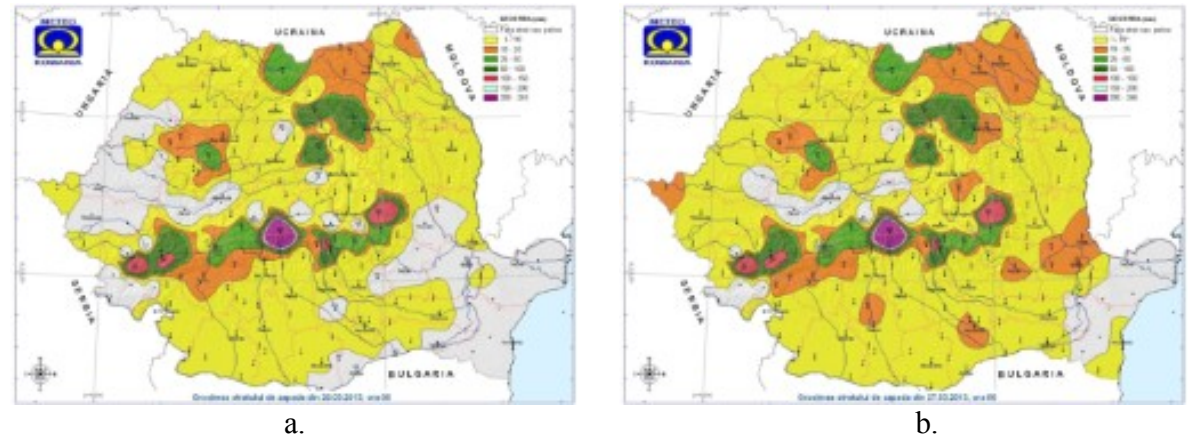

Fig.6 Snow covers depths: : March , 25 ${ }^{\text {th }}(\mathrm{a}), 26^{\text {th }}(\mathrm{b})$, (Source: NMA, 2013)

\section{Results}

Using the ALARO numerical model data - the sea level pressure and $850 \mathrm{hPa}$ temperature maps (Fig. 7) - denote that the polar air mass has a greatest influence over the northern part of Moldova extended along the Curvature Carpathians to the Bãrãgan area, pushing the warmer air mass generating the blizzard phenomenon. This fact it can be seen on the sounding diagrams for Bucharest.

The Bucharest soundings on the $26^{\text {th }}$ of March, at 00:00 and 12:00 GMT (Fig. 8), show the existence in the lower troposphere of a warm air mass, which is then pushed up to higher levels once that the cold air mass sinks down, the thermal inversion occurring below $900 \mathrm{hPa}$, at a height of approximately $700-800 \mathrm{~m}$, knowing that the blizzard mainly occurs in the lower troposphere. The soundings also show a wind shear at the sea level pressure from the NE which is increasing in upper levels. The warmer air mass was over the SW Romania. 


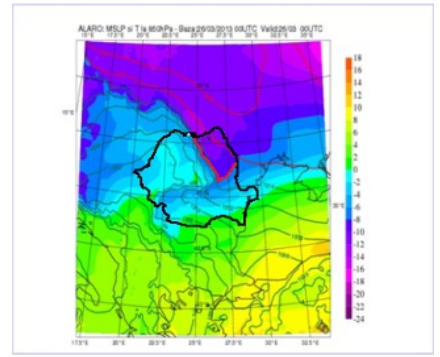

a.

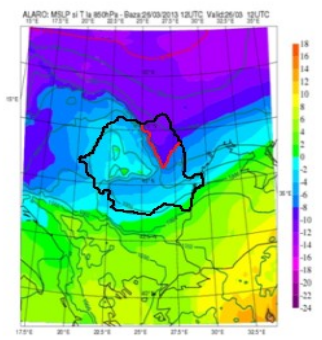

b.

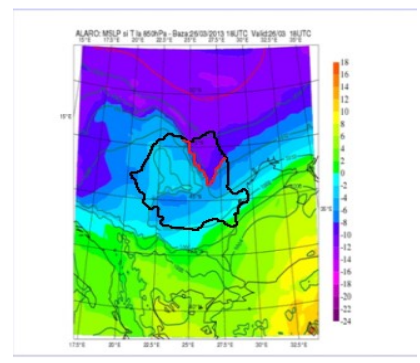

c.

Fig.7 Sea level pressure and $850 \mathrm{hPa}$ air temperature maps of 26 March 2013 ALARO model reconsidered, a) 00:00 UTC time; b) 12:00 UTC time; c) 18:00 UTC time, (Source: ANM, 2013)

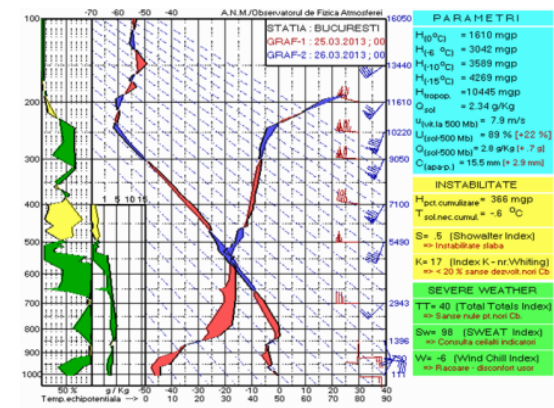

a.

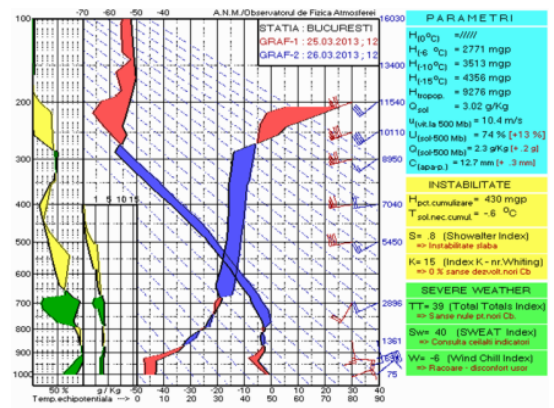

b.

Fig.8 Aerologic diagram in Bucharest on March 26, 2013: a) 00:00 UTC time; b) 12:00 UTC time, (Source:NMA, 2013)

\subsection{Weather warnings}

National Meteorological Administration first issued a yellow code, then an orange one and again a yellow code (Fig. 9).

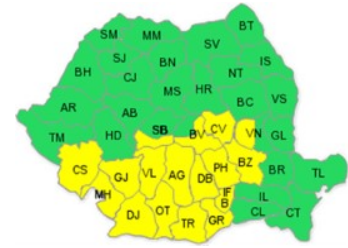

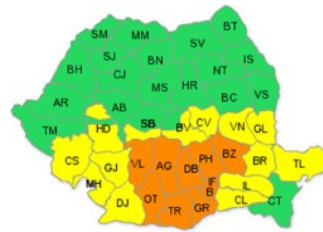

b.

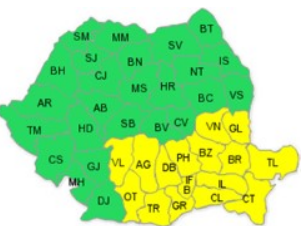

c.

Fig. 9 a) Yellow code alert since 20 o'clock 25.03 - 26.03 at 4; b) Orange code warning at $26.0304-26.0314$ hours; c) Yellow code warning on 26 March at 20,

(Source: NMA, 2013) 


\subsection{Consequences}

On the $26^{\text {th }}$ and the $27^{\text {th }}$ of March 2013, 600 schools and high schools were closed in Bucharest and Buzãu county, A1 and A2 highways have been completely closed down to traffic because of the drifting snow piling on the road(Fig. 10)

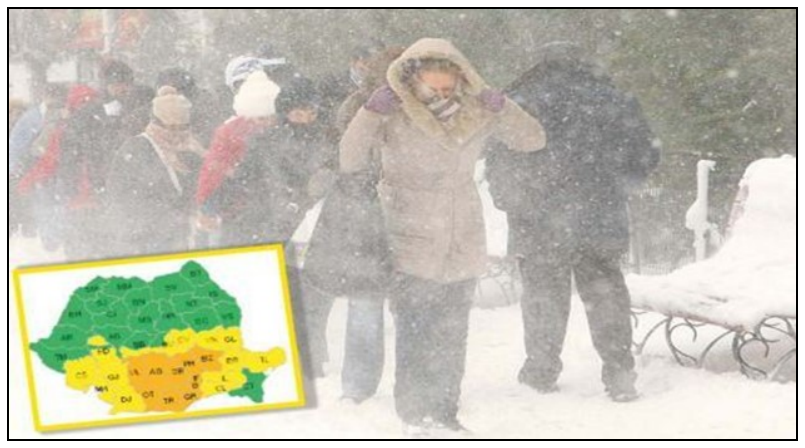

Fig. 10 Images from Bucharest capital-city during the blizzard of March 26, 2013, (Source: http://www.click.ro/news/national/)

\section{Sumary}

The blizzard phenomenon from the $24^{\text {th }}$ until the $26^{\text {th }}$ of March 2013:

1. was a classic episode of blizzard produced by the violent clash between a Mediterranean cyclone and a Greenland anticyclone;

2. such phenomena usually occur on cut-off synoptic conditions in specific to the negative phase of the North Atlantic Oscillation favoring blizzards in mid latitude implicit regions;

3. the phenomenon was severe because of the great air-pressure horizontal lopes rates;

4. a cold air mass of polar origins stagnate over the northern parts of the Moldova province, extending towards the SE, along the Curvature Carpathian foothills and pushing the warmer air mass aloft

5. from a synoptic point of view, according to Bălescu and Beşleagã's classification(1962), this blizzard episode falls into the type III category;

6. the blizzard episode lasted for about 11 hours and centered over the Griviţa (Ialomiţa) locality;

7. the most intensely affected areas were: Bucharest, Ialomiţa, Buzãu and Galaţi counties;

8. the climatologic analysis over a period of 113 years (1900-2013) revealed that in total there were 42 episodes of blizzard (40 in March and two in April), with a total duration of 102 days (98 March and 4 April); 
9. the latest date on which blizzard conditions occurred was, from the $8^{\text {th }}$ until the $9^{\text {th }}$ of April 1911.

\section{Bibliography}

Bãlescu, I. Oprea, Beşleagã, N. Nicolae (1962) "Viscolele în Republica Popularã România”, C.S.I. Institutul Meteorologic;

Bălteanu Dan, Alexe Rădița (2001), "Hazarde naturale şi antropogene", Editura Corint, București;

Bogdan Octavia, Niculescu Elena (1999), "Riscurile climatice din România", Academia Română, Institutul de Geografie, Tipar Compania Sega International, București; Ciulache S., Ionac N. (1995), "Fenomene atmosferice de risc şi catastrofe climatice”, Editura Ştiinţifică, Bucureşti;

Moldovan Florin ( 2003), "Fenomene climatice de risc", Editura Echinox, Cluj-Napoca *** (2008), Clima României, Editura Academiei Române, București; www. meteoromania.ro; www.nooa.org.com; www.weather.uwyo.edu; www.wetter3.de; 